OBITUARY

Published June 24, 2019

\title{
Charlie van der Horst (1952-2019)
}

Charlie van der Horst, an emeritus professor at the University of North Carolina and a friend of Pathogens and Immunity, disappeared from sight on Friday, June 14 during a marathon swim in the Hudson River. His death was confirmed. Few who knew him would call him Charles as formality was not his strong-suit. Charlie was born in Holland to a Dutch father and a Polish Holocaust survivor mother. His family moved to the Buffalo, New York area and sent Charlie to school at Andover. He attended Duke University where he captained the varsity

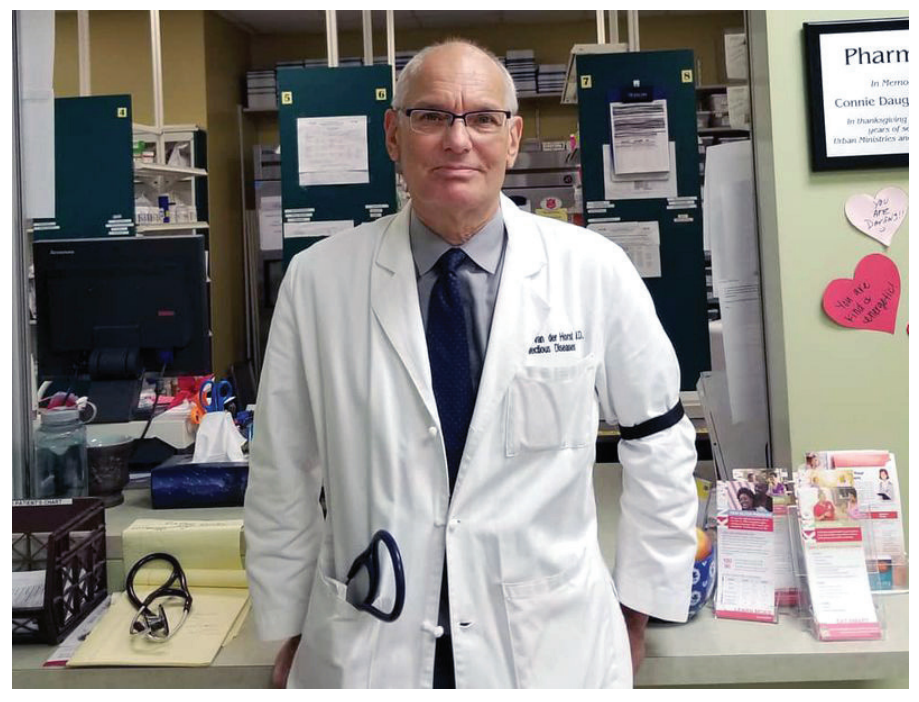
swim team in 1973-74. He remained a powerful swimmer, competing often in national Masters' competitions. He received his MD degree from Harvard in 1979 and trained in medicine at Montefiore Medical Center and infectious diseases at the University of North Carolina. He was an expert in the management of fungal diseases and when the AIDS epidemic began, he knew he had to commit his career to AIDS research and care. He led a highly successful AIDS Clinical Trials Unit at the University of North Carolina and was a respected leader in this national consortium who gained international recognition and respect for his work. More than most anyone else I know, Charlie was driven to fight for justice, anywhere, any time. At the 2000 IAS meeting in Durban, South Africa he recognized that the greater AIDS need was in the developing world and he redirected his entire career towards the development of research and care programs in Africa. When Ebola hit West Africa, Charlie rushed to Liberia to help. In the U.S., Charlie was on the front lines urging his state legislature to deal fairly with all North Carolinians, working hard to fight for equity in health care. He was beloved by so many, respected for his talents, admired for his decency. He was, as my grandmother would have said - a mentsch — and more. Our world is lucky to have had him and is diminished by his loss.

-Michael M. Lederman

DOI

10.20411/pai.v4i1.305 


\section{FOOTNOTES}

Submitted June 24, 2019 | Accepted June 24, 2019 | Published June 24, 2019

\section{COPYRIGHT}

Copyright (C) 2019 Pathogens and Immunity

This is an open-access article distributed under the terms of the Creative Commons Attribution 4.0 International License. 